\title{
Socio-demographic characteristics and sexual health related attitudes and practices of men having sex with men in central and southern Malawi
}

\author{
P.R.T. NTATA ${ }^{1}$, A.S. MUULA ${ }^{2 *}$ and S. SIZIYA ${ }^{3}$ \\ ${ }^{1}$ Department of Sociology, Chancellor College, University of Malawi, Zomba, Malawi \\ ${ }^{2}$ Department of Community Health, College of Medicine, University of Malawi, Private Bag 360, Chichiri, \\ Blantyre 3, Malawi \\ ${ }^{3}$ Department of Community Medicine, School of Medicine, University of Zambia, Lusaka, Zambia
}

\begin{abstract}
An exploratory study of men having sex with men (MSM) was conducted in central and southern Malawi in order to understand their socio-demographic characteristics, sexual behaviours, and perceptions about confidentiality and stigma. A total of 97 men participated in the study of whom $84(86.6 \%)$ were in the age group 17-32 years. The majority, 73 (75.3\%) of MSM had never married, $26(32.5 \%)$ reported not always using condoms during sexual intercourse, and $23(23.7 \%)$ had ever received money or gifts in exchange of sex. Only $17(17.5 \%)$ of the participants reported being exposed to HIV prevention messages targeted at MSM. Fear of sexual orientation disclosure and discrimination were reported by 27 (30.7\%) of MSM. Many of the study participants reported that HIV intervention programmes are not accessible to them. In conclusion, HIV intervention programmes may not be reaching out to the majority of MSM. We suggest an exploration of the feasibility of HIV prevention interventions targeting MSM in this country where the practice is illegal.
\end{abstract}

Key words: sexual orientation, men, attitudes, practices, HIV, prevention, Malawi

\section{Introduction}

Human immunodeficiency virus (HIV) infection is a major public health problem in Malawi where an estimated $12 \%$ of adults 15 to 49 years are infected (NSO, 2005). HIV infection prevalence is much higher among women attending antenatal care, where in urban areas prevalence estimates of 30\% have been reported since the late 1990s (Bello et al., 2006; Semba et al., 1999). There is evidence however that prevalence estimates and incidence of infection have reduced somewhat and stabilized in recent years (Bello et al., 2006; Hallet et al., 2006).

While the national effort to prevent further HIV transmission and to provide treatment to all geographical and diverse demographic groups of the population has been scaled up, there has been 'guarded' interest in interventions aimed to prevent HIV spread among men having sex with other men (MSM) in the country. Same sex male partnerships are illegal in Malawi and marriage is only permitted in a heterosexual relationship. Muula (2007a) has reported an analysis of newspaper articles in the country on several aspects of homosexuality or men having sex with men. The report suggested that MSM was perceived as rare in the country, although the risk of HIV transmission was recognised.

There is paucity of data on MSM in Africa. Simooya et al. (1995) have reported on MSM in prison environments in Zambia. Furthermore, MSM is perceived to result from a foreign influence and is it against the cultural tenets of Malawi. As a result some key policy makers have denied the possibility of MSM activity in the country (Muula, 2007a).

Considering the scale of the HIV epidemic in Africa, limited data on MSM have come from subSaharan Africa presumably because research assume no public health problem or do not know how to work with MSM in these settings where MSM is illegal. The available evidence however highlights to multiple opportunities for interventions that may reduce health risk. In a study in South Africa, Parry et al. (2008) have reported high HIV knowledge, low prevention practice and associated drug use among MSM. Baral et al. (2007) and Liu et al. (2006) have reported that HIV prevalence is much higher among MSM compared to the 'general' community. This has also been shown in other settings such as Thailand and China where studies on MSM in relation to HIV suggest

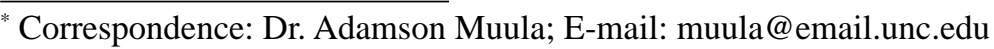


that HIV prevalence may be much higher than the 'general' or heterosexual population (CDC, 2006; Liu et al., 2006). However differences in risk behaviours among MSM between different settings may occur (Parry et al., 2008). Recently, Sanders et al., (2007) have reported that less than $2 \%$ of MSM in Kenya were using illicit drugs whereas in South Africa the prevalence has been reported to exceed 25\% (Parry et al., 2008). Overall however, a review of HIV prevalence among MSMs across the world found no reliable estimates of HIV prevalence from Africa (Cáceres et al., 2006).

Despite the above these considerations, the Malawi National AIDS Commission in collaboration with the Department of Correctional Services facilitated the drafting of legislation that will allow conjugal visit among incarcerated males in order to 'prevent' MSM activity within prisons. In some sense therefore this is an acknowledgement of the practice of MSM within prison environments. The prevalence of MSM outside prison and jails in Malawi remains understudied and under-appreciated. This exploratory study aimed at understanding MSM socio-demographic characteristics, sexual health related attitudes and practices. It is envisaged that this information may encourage research and programmatic interest in efforts aimed to prevent the spread of HIV in Malawi.

\section{Materials and Methods}

\section{Study area}

The study was conducted in the central and southern regions of Malawi and included Blantyre, Zomba, Lilongwe, Machinga, Mangochi and Dedza. These districts were purposefully selected. Anecdotal evidence, including media reports, suggested that most samesex activities were more concentrated in these areas. The selected regions are the most socio-economically developed districts in Malawi.

\section{Study participant recruitment and questionnaire administration}

A snowballing method was used to recruit MSM from the general community in November 2006. Initially, seven MSM were identified and requested to recruit potential participants who were known to them as men having sex with men. A standard questionnaire was administered to the study participants by trained research staff. Information sought included: age; marital status; residence (urban, peri-urban, rural); educational level; sexual practices; disclosure of sexual orientation and preferences and HIV prevention measures.

\section{Data analysis}

Data were analysed using SPSS version 14.0 (SPSS, Chicago, Illinois, United States of America). Frequency and proportions of selected socio-demographic variables, knowledge, perceptions and behaviours were obtained. Residence status was categorised as "urban, semi-urban and rural" as per Malawi National Statistical Office guidelines (Muula, 2007b). These guidelines define rural, urban and peri-urban area status based on a decision by the Office of President and Cabinet and not based on development indicators or population congregation as is the case elsewhere (Magee, 2000; Crandall \& Weber, 2005).

\section{Ethical considerations}

All respondents participated only after giving verbal informed consent. Only men who were having sex with other men were involved in questionnaire distribution and collection. The involvement of MSM as research assistants possibly minimised potential stigma and discrimination. This study was exempt from full ethical review by the National Research Council of Malawi.

\section{Results}

A total of 97 men having sex with men (MSM) were recruited and participated in the study and $83.5 \%, 8.2 \%$ and $8.2 \%$ were from urban, peri-urban and rural residence respectively. Most, 73 (75.3\%) of MSM reported being residents of Lilongwe, Zomba or Blantyre, the three cities in the southern and central region of the country, $12.4 \%$ were residents of Liwonde, and the rest $(12.3 \%)$ were residents of Mangochi, Balaka, Dedza, and Mozambique. The majority of MSM, 94 (96.9\%) were of Malawian nationality, 73 (75.3\%) had never been married, and 90 (92.8\%) were Christians. The age distribution of the participants was as follows: 17 (17.5\%) MSM were in group 18-22 years, $47(48.5 \%)$ in $23-27$ years, $20(20.6 \%)$ in $28-32$ years, $10(10.3 \%)$ in 33-37 years, and 3 (3.1) were in the age group $\geq 38$ years. Most of MSM, 67 (69.1\%) had no children, 17 (17.5\%) had one child, and 13 (13.45) had up to five children. Further socio-demographic description of the study participants is reported in Table 1. 
Table 1: Socio-demographic characteristics of men having sex with men in Malawi

\begin{tabular}{|c|c|c|c|c|}
\hline \multirow[b]{2}{*}{ Factor } & \multirow[b]{2}{*}{ Response } & \multirow{2}{*}{$\begin{array}{l}\text { Total } \\
\text { n (\%) }\end{array}$} & \multicolumn{2}{|c|}{ Age group (years) } \\
\hline & & & $\begin{array}{l}<28 \\
\text { n (\%) }\end{array}$ & $\begin{array}{l}\geq 28 \\
\text { N (\%) }\end{array}$ \\
\hline \multirow[t]{2}{*}{ Marital status } & Never married & $73(75.3)$ & $58(90.6)$ & 15 (45.5) \\
\hline & Ever married to female* & $24(24.7)$ & $6(9.4)$ & 18 (54.6) \\
\hline \multirow{2}{*}{ Education } & Up to secondary & 49 (50.5) & $36(56.3)$ & $13(39.4)$ \\
\hline & Post-secondary & 48 (49.5) & $28(43.7)$ & $20(60.6)$ \\
\hline \multirow[t]{2}{*}{ Religion } & Christian & $90(92.8)$ & $60(93.8)$ & 30 (90.9) \\
\hline & Other** & $7(7.2)$ & $4(6.3)$ & $3(9.1)$ \\
\hline \multirow[t]{2}{*}{ Race } & Black & $91(93.8)$ & $60(93.8)$ & 31 (93.9) \\
\hline & Other & $6(6.2)$ & $4(6.3)$ & $2(6.1)$ \\
\hline \multirow[t]{2}{*}{ Nationality } & Malawi & $94(96.9)$ & $64(100)$ & $30(90.9)$ \\
\hline & Other & $3(3.1)$ & $0(0)$ & $3(9.1)$ \\
\hline \multirow[t]{5}{*}{ Occupation } & Student in school & $14(14.4)$ & $11(17.2)$ & $3(9.1)$ \\
\hline & Student in college & $12(12.4)$ & $11(17.2)$ & $1(3.0)$ \\
\hline & Professional $* * *$ & $39(40.2)$ & $18(28.1)$ & $21(63.6)$ \\
\hline & Business & $18(18.6)$ & $13(20.3)$ & $5(15.2)$ \\
\hline & Other & $14(14.4)$ & $11(17.2)$ & $3(9.1)$ \\
\hline
\end{tabular}

Notes: * ever married include currently married (19), divorced (2), and co-habiting (3); ** other include: Moslem (6), ***include: teachers, health professionals, accountants

Just under half (48.5\%) of MSM reported that they were attracted to men only, $23(23.7 \%)$ reported that they had ever had sex in exchange for money or gifts, and
$26(32.5 \%)$ reported that they did not consistently use condoms (Table 2).

Table 2: Sexual practices among men having sex with other men in Malawi

\begin{tabular}{lllll}
\hline & & \multicolumn{2}{l}{ Total } & \multicolumn{2}{l}{ Age group (years) } \\
Factor & Response & & $<\mathbf{2 8}$ & $\geq \mathbf{2 8}$ \\
& & n (\%) & n (\%) & n (\%) \\
\hline Age at first sexual activity (years) & $<16$ & $36(37.1)$ & $25(39.1)$ & $11(33.3)$ \\
& $16+$ & $61(62.9)$ & $39(60.9)$ & $22(66.7)$ \\
Whom do you desire to have sexual relationship with? & Men only & $47(48.5)$ & $36(56.3)$ & $11(33.3)$ \\
& Other & $50(51.5)$ & $28(43.8)$ & $22(66.8)$ \\
Ever had anal penetration with someone who didn't want & Yes & $21(21.6)$ & $15(23.4)$ & $6(18.2)$ \\
to use a condom & & & & \\
& No & $76(78.4)$ & $49(76.6)$ & $27(81.8)$ \\
Always used condom & Yes & $54(67.5)$ & $35(68.6)$ & $19(65.5)$ \\
& No & $26(32.5)$ & $16(31.4)$ & $10(34.4)$ \\
Ever had sex with another man to receive money or gift & Yes & $23(23.7)$ & $17(26.6)$ & $6(18.2)$ \\
& No & $74(76.3)$ & $47(73.4)$ & $27(81.8)$ \\
$\begin{array}{l}\text { Did anything to protect self from HIV/AIDS and other sexu- } \\
\text { ally transmitted infections }\end{array}$ & Yes & $82(84.5)$ & $53(82.8)$ & $29(87.9)$ \\
& No & $15(15.5)$ & $11(17.2)$ & $4(12.1)$ \\
\hline
\end{tabular}


Close to half (45.4\%) had heard about MSM in school, and $39.2 \%$ had known about MSM before attaining the age of 16 years. However, only $17(17.5 \%)$ of the respondents reported being exposed to HIV prevention messages targeting MSM. Some $58.8 \%$ of the MSM had ever obtained HIV voluntary counselling and testing services (Table 3).

Table 3: Knowledge about men having sex with other men and HIV in Malawi

\begin{tabular}{|c|c|c|c|c|}
\hline \multirow{3}{*}{ Factor } & \multirow{3}{*}{ Response } & \multirow{3}{*}{$\begin{array}{l}\text { Total } \\
\text { N (\%) }\end{array}$} & \multicolumn{2}{|c|}{ Age group (years) } \\
\hline & & & $<28$ & $\geq 28$ \\
\hline & & & n (\%) & n (\%) \\
\hline \multirow{2}{*}{$\begin{array}{l}\text { Age when first heard of the term ho- } \\
\text { mosexuality }\end{array}$} & $<16$ years & 38 (39.2) & $29(45.3)$ & $9(27.2)$ \\
\hline & $\geq 16$ years & $59(60.8)$ & $35(54.7)$ & $24(72.7)$ \\
\hline \multirow{4}{*}{$\begin{array}{l}\text { Place where first heard of homosexu- } \\
\text { ality }\end{array}$} & Home & $9(9.3)$ & $6(9.4)$ & $3(9.1)$ \\
\hline & School & $44(45.4)$ & $27(42.2)$ & 17 (51.5) \\
\hline & Electronic/media & $24(24.7)$ & 17 (26.6) & $7(21.2)$ \\
\hline & Friends & $20(20.6)$ & 14 (21.9) & $6(18.2)$ \\
\hline \multirow{2}{*}{$\begin{array}{l}\text { Ever received any health messages } \\
\text { targeting MSM }\end{array}$} & Yes & 17 (17.5) & $10(15.6)$ & $7(21.2)$ \\
\hline & No & $80(82.5)$ & $54(84.4)$ & $26(78.8)$ \\
\hline \multirow{2}{*}{$\begin{array}{l}\text { Ever discussed homosexuality in rela- } \\
\text { tion to HIV/AIDS }\end{array}$} & Yes & 69 (71.1) & $44(68.8)$ & 25 (75.8) \\
\hline & No & $28(28.9)$ & $20(31.3)$ & $8(24.2)$ \\
\hline \multirow[t]{2}{*}{ Ever gone for VCT } & Yes & 57 (58.8) & $37(57.8)$ & $20(60.6)$ \\
\hline & No & $40(41.2)$ & $27(42.2)$ & $13(39.4)$ \\
\hline
\end{tabular}

The majority (90.6\%) of MSM felt comfortable with their sexual orientation. Despite of this, and $90.7 \%$ had, however, kept their sexual orientation secret from friends and family members. Some $56.4 \%$ of the participants reported having ever denied that they were MSM but $34 \%$ wished that other people knew about their sexual orientation. Twenty (30.7\%) of the participants reported that they feared stigma and discrimination should they disclose to other people that they were MSM. Among those who reported to have disclosed to other people that they were MSM, 28 (28.9\%) had disclosed to close friends, $12(12.4 \%)$ to workmates, $6(6.2 \%)$ to family members and 1 to a marital partner (Table 4). 
Table 4: Attitudes among men having sex with men in Malawi, 2007

\begin{tabular}{|c|c|c|c|c|}
\hline \multirow[b]{2}{*}{ Factor } & \multirow[b]{2}{*}{ Response } & \multirow[b]{2}{*}{$\begin{array}{l}\text { Total } \\
\text { n (\%) }\end{array}$} & \multicolumn{2}{|c|}{ Age group (years) } \\
\hline & & & $\begin{array}{l}<28 \\
\text { n (\%) }\end{array}$ & $\begin{array}{l}\geq 28 \\
\text { n (\%) }\end{array}$ \\
\hline \multirow[t]{2}{*}{ Comfortable with sexual orientation } & Yes & 87 (90.6) & 59 (93.7) & $28(84.8)$ \\
\hline & No & $9(9.4)$ & $4(6.3)$ & $5(15.2)$ \\
\hline \multirow{2}{*}{$\begin{array}{l}\text { Sexual orientations kept secret from } \\
\text { non-MSM friends/ family }\end{array}$} & Yes & $88(90.7)$ & $59(92.2)$ & 29 (87.9) \\
\hline & No & $9(9.3)$ & $5(7.8)$ & $4(12.1)$ \\
\hline \multirow[t]{3}{*}{ Reasons for keeping secret } & Fear of parents/ relatives & $45(51.1)$ & $35(58.3)$ & $10(34.5)$ \\
\hline & Fear of stigma & $27(30.7)$ & $18(30.0)$ & $9(31.0)$ \\
\hline & Others & $16(18.2)$ & 6 & $10(34.5)$ \\
\hline \multirow[t]{2}{*}{ Ever denied being gay } & Yes & $53(56.4)$ & $39(62.9)$ & $14(43.8)$ \\
\hline & No & $41(43.6)$ & $23(37.1)$ & $18(56.3)$ \\
\hline \multirow{2}{*}{$\begin{array}{l}\text { Would want other people who are not } \\
\text { gay to know your sexual orientation }\end{array}$} & Yes & $33(34.0)$ & $23(35.9)$ & $10(30.3)$ \\
\hline & No & $64(66.0)$ & $41(64.1)$ & $23(69.7)$ \\
\hline \multirow{2}{*}{$\begin{array}{l}\text { Wished sometimes that was not } \\
\text { MSM }\end{array}$} & Yes & $35(36.8)$ & $22(35.5)$ & $13(39.4)$ \\
\hline & No & $60(63.2)$ & $40(64.5)$ & $20(60.6)$ \\
\hline \multirow{2}{*}{$\begin{array}{l}\text { Ever tried to change from being } \\
\text { MSM }\end{array}$} & Yes & $23(24.0)$ & $14(22.2)$ & $9(27.3)$ \\
\hline & No & $73(76.0)$ & $49(77.8)$ & 24 (72.7) \\
\hline
\end{tabular}

\section{Discussion}

In an exploratory study of MSM in Malawi, we report several socio-demographic and sexual behavioural variables. As an exploratory study with a snowballing sampling, this study provides critical data that will potentially improve our understanding on the issue of MSM in a southern African country where MSM is illegal and HIV prevalence in the general adult population is estimated at $12 \%(\mathrm{NSO}, 2005)$. This study though, being cross sectional in design and not a probability sample, we can neither ascribe causation to any of the factors identified or confirm that the frequencies and proportions of the various attributes studied are representative of the general MSM population in Malawi. Furthermore, because of the snowballing nature of participant recruitment, it is likely that respondents recruited potential respondents who were similar to themselves or within their own sexual networks (Rubin et al., 1994). Study participants also self-reported in response to the questions asked. Gallo et al. (2007) found that sex workers in Kenya under- reported unprotected sexual intercourse which was detected via biomarkers of semen. In a study like ours, there is also a possibility that respondents may have mis-reported either intentionally or inadvertently. The use of data collection assistants who were also MSM was intended to minimise intentional mis-reported as we expected that study participants were likely to be open to other MSM.

Despite the limitations of the study as outlined above, there are several key findings worth consideration. These are that marriage with females is not rare among MSM; individuals are introduced to know about MSM early on in life; individuals get to know about homosexuality in diverse settings and largely in schools and the majority identified in this study were Malawian nationals. Furthermore, unprotected sexual intercourse was reported by about a third and the majority of the respondents had not been exposed to HIV prevention messages specifically targeting MSM. Most of the study participants were well aware of the legal provisions proscribing MSM, and feared stigma and discrimination from the society around them. 
The current legal situation of MSM in Malawi is problematic. It is illegal for men to have sex with other men. In an environment where HIV infection prevalence in adults is $12 \%$ and with the "bridging" or mixing between heterosexual and MSM populations, the challenge is how public health HIV prevention programmes designers and implementers deliver services that would be accessible and appropriate to all people within the country despite their sexual orientations and behaviours?

According to the PRECEED/PROCEED model of health promotion (Green \& Kreuter, 1991), an individual is likely to adopt a healthy behaviour if she/he has the appropriate knowledge, attitude, and is exposed to reinforcing and enabling factors (friends, family and health workers). In Malawi, it appears that MSM do not have access to relevant HIV messages that will potentially influence their knowledge levels and attitudes. The limited understanding of risks associated with MSM may lead to failure in recognising and protecting oneself from high risk sexual behaviours. Furthermore, the fact that many MSM may hide their sexuality from significant others and possibly health care workers, may result in their missing out from the available preventive services.

Designing and providing prevention messages and other programmes in an environment where the primary behaviour is illegal is difficult but not impossible. In selected settings in Europe, Asia and North America, use of specific narcotic and psycho-stimulant drugs is illegal. Yet, programs commonly referred to as "harm reduction" initiatives are implemented (Christie et al., 2008; Paterson \& Panessa, 2008). Although it may appear a strange concept in most African settings, various forms of 'harm reduction' programmes are already being implemented in the prevention of HIV. For instance, in many cultures and religions, concurrent sexual partnerships, extra-marital and pre-marital sex are discouraged. Encouraging correct and consistent condom use where sexual intercourse occurs in such situations has potential to prevent HIV spread, thereby minimize the adverse effect that may have occurred following or during a society-proscribed activity. Appropriate HIV prevention messages and other interventions targeting MSM are therefore required in Malawi in order to curb the spread of HIV and other sexually transmitted infections among MSM. Léobon \& Frigault (2008) reminds researchers and programme planners that MSM are a heterogeneous group with different socio-demographic characteristics. Our study has shown too that MSM were not a homogenous group. Young and old, married and unmarried, rural and urban, and of religious persuasions self identified themselves as MSM. Interventions programmes would have to take these differences in consideration in approach in order to be sufficiently effective.

In conclusion, HIV intervention programmes may not be reaching out to the majority of MSM. We suggest an exploration of the feasibility of effective HIV prevention interventions targeting MSM in this country, where MSM is illegal. Simooya et al. (2001) in a study in Zambia have reported the difficulty in providing condoms in prisons for MSM when the practice is illegal in that country. We believe that even outside the prison environment, policy makers often have dilemma on how to provide prevention services when same sex practices are illegal. We are also unaware of any studies that have assessed HIV or other sexually transmitted infections prevalence among MSM in Malawi. We propose that studies be designed to obtain these data.

\section{Conflict of interest}

The authors declare that they have no conflict of interest.

\section{Acknowledgements}

We are grateful to all men who accepted to be study participants. Funding for the study was obtained from the Harare office of the Humanistisch Instituut voor Ontwikkelingssamenwerking (HIVOS), a Dutch nongovernmental organization.

Received 17 April 2008

Revised 20 May 2008

Accepted 21 May 2008

\section{References}

Baral, S., Sifakis, F., Cleghorn, F. \& Beyrer, C. (2007) Elevated risk for HIV infection among men who have sex with men in low- and middle-income countries 2000-2006: a systematic review. PLoS Medicine 4 (12), e339.

Bello, G.A., Chipeta, J. \& Aberle-Grasse, J. (2006) Assessment of trends in biological and behavioural surveillance data: is there any evidence of declining HIV prevalence or incidence in Malawi? Sexually Transmitted Infections 82 (Suppl 1), i9-13.

Cáceres, C., Konda, K., Pecheny, M., Chatterjee, A. \& Lyerla, R. (2006) Estimating the number of men who have sex with men in low and middle income countries. Sexually Transmitted 
Infections 82 (Suppl 3), iii3-9.

CDC (2006) HIV prevalence among populations of men who have sex with men-Thailand, 2003 and 2005. Mortality and Morbidity Weekly Report $55,844-848$.

Christie, T., Groarke, L. \& Sweet, W. (2008) Virtue ethics as an alternative to deontological and consequential reasoning in the harm reduction debate. International Journal on Drug Policy 19, 52-58.

Crandall, M. \& Weber B. (2005) Defining Rural Oregon: an Exploration. Oregon: Rural Studies Program, Oregon State University, p 13.

Gallo, M.F., Behets, F.M., Steiner, M.J., Thomsen, S.C., Ombidi, W., Luchters, S., Toroitich-Ruto, C. \& Hobbs, M.M. (2007) Validity of self-reported 'safe sex' among female sex workers in Mombasa, Kenya-PSA analysis. International Journal of Sexually Transmitted Diseases and AIDS 18, 33-38.

Green L.W. \& Kreuter M.W. (1991) Health promotion: An Educational and Environmental Approach. ( $2^{\text {nd }}$ Edition), Mountain View, Mayfield, California, United States of America.

Hallett, T.B., Aberle-Grasse, J., Bello, G., Boulos, L.M., Cayemittes, M.P., Cheluget, B., Chipeta, J., Dorrington, R., Dube, S., Ekra, A.K., GarciaCalleja, J.M., Garnett, G.P., Greby, S., Gregson, S., Grove, J.T., Hader, S., Hanson, J., Hladik, W., Ismail, S., Kassim, S., Kirungi, W., Kouassi, L., Mahomva, A., Marum, L., Maurice, C., Nolan, M., Rehle, T., Stover, J. \& Walker, N. (2006) Declines in HIV prevalence can be associated with changing sexual behaviour in Uganda, urban Kenya, Zimbabwe, and urban Haiti. Sexually Transmitted Infections 82 (Suppl 1), i1-8.

Léobon, A. \& Frigault, L.R. (2008) Frequent and systematic unprotected anal intercourse among men using the Internet to meet other men for sexual purposes in France: results from the “Gay Net Barometer 2006” Survey. AIDS Care 20, 478-484.

Liu, H., Yang, H., Li, X., Wang, N., Liu, H., Wang, B., Zhang, L., Wang, Q. \& Stanton B. (2006). Men who have sex with men and human immunodeficiency virus/sexually transmitted disease control in China. Sexually Transmitted Diseases 33, 68-76.

Magee, G.C. (2000) Procedural skills rurality index for the medical community. Canadian Journal of Rural Medicine 5, 8.
Muula, A.S. (2007a) Perceptions about men having sex with men in southern African country: case study of print media in Malawi. Croatian Medical Journal 48, 398-404.

Muula, A.S. (2007b) How do we define 'rurality' in the teaching on medical demography? Rural and Remote Health, 7(1):653. Available from: http://www.rrh.org.au

NSO (2005) National Statistical Office and ORC Macro. Malawi Demographic and Health Survey 2004. Calverton, Maryland: NSO and ORC Macro.

Parry, C., Petersen, P., Dewing, S., Carney, T., Needle, R., Kroeger, K. \& Treger, L. (2008) Rapid assessment of drug-related HIV risk among men who have sex with men in three South African cities. Drug and Alcohol Dependence 95, 45-53.

Paterson, B.L. \& Panessa, C. (2008) Engagement as an ethical imperative in harm reduction involving at-risk youth. International Journal on Drug Policy 19, 24-32.

Rubin, K.H., Lynch, D., Coplan, R., Rose-Krasnor, L. \& Booth, C.L. (1994) "Birds of a feather...": behavioral concordances and preferential personal attraction in children. Child Development 65, 1778-1785.

Sanders, E.J., Graham, S.M., Okuku, H.S., van der Elst, E.M., Muhaari, A., Davies, A., Peshu, N., Price, M., McClelland, R.S. \& Smith, A.D. (2007) HIV-1 infection in high risk men who have sex with men in Mombasa, Kenya. AIDS 21, 2513-2520.

Semba, R.D., Kumwenda, N., Hoover, D.R., Taha, T.E., Quinn, T.C., Mtimavalye, L., Biggar, R.J., Broadhead, R., Miotti, P.G., Sokoll, L.J., van der Hoeven, L. \& Chiphangwi, J.D. (1999) Human immunodeficiency virus load in breast milk, mastitis, and mother-to-child transmission of human immunodeficiency virus type 1. Journal of Infectious Diseases 180, 93-98.

Simooya, O., Phiri, A., Sanjobo, N. \& Sichilima, W. (1995) Sexual behaviour and issues of HIV/ AIDS prevention in an African prison. AIDS 9, 1388-1389.

Simooya, O.O., Sanjobo, N.E., Kaetano, L., Sijumbila, G., Munkonze, F.H., Tailoka, F. \& Musonda, R. (2001) 'Behind walls': a study of HIV risk behaviours and seroprevalence in prisons in Zambia. AIDS 15, 1741-1744. 